\title{
Analysis of the Studies Published on Business Strategy Game and Learning Strategic Management in the Web of Science Database
}

\author{
https://doi.org/10.3991/ijet.v15i23.18789
}

\author{
Alper Cavus $(\bowtie)$ \\ Near East University, Nicosia, Turkey \\ alper.cavus@neu.edu.tr
}

Alfiya R. Masalimova

Kazan Federal University, Kazan, Russia

Vasil N. Farrakhov

Almetyevsk State Oil Institute, Almetyevsk, Russia

Svetlana G. Kashina

Kazan State University of Architecture and Engineering, Kazan, Russia

Zhanna M. Sizova,

I.M. Sechenov First Moscow State Medical University, Moscow, Russia

Olga V. Popova,

Financial University under the Government of the Russian Federation,

Moscow, Russia

\begin{abstract}
Although the variety of computer-based games offered for strategic management, ease of use and the number of games available in the market has decreased due to multiple factors, it has also increased. Depending on the criterion of the objectively measured learning outcomes, various games that have been studied to date yield higher results than those obtained by case approach as an alternative teaching strategy. Very little research has been conducted on factors that facilitate play, leading to effective learning outcomes in a business gaming environment. The general purpose of this research is to determine the work conducted on Business Strategy Game (BSG) and Learning Strategic Management. This study was conducted using qualitative research method, document analysis and related content analysis, studying the keywords 'Business Strategy Game and Learning Strategic Management' in the Web of Science database, based on the analysis of the documents. The studies in the Web of Science database were analysed according to years, the Web of Science categories, the research area, country/types and writing languages. The analysis of the studies in the Web of Science database for BSG and learning strategic management emerged with the resulting content. A total of 39 studies were carried out and it was concluded that the most common transactions were made in 2019. However, the first study was conducted in 1995. In the literature
\end{abstract}


review, the year 2019 has the most reads, which were mostly published articles. According to the Web of Science field type, it was concluded that there were studies mostly in the Education and Educational Research field and it was also concluded that 38 of these studies were written in English.

Keywords-Learning, technology, Business Strategy Game, Learning Strategic Management, Web of Science

\section{Introduction}

As the number of people born from the beginning of the 21 st century to the present has increased, the applications made for the 21 st-century generation have also diversified. Net citizens (netizens), also called digital natives, are a born generation. The interpretation of technology is as if there is no life without technology in daily life with the generation of this new age, which is referred to by different names, internalised. [16]. With the rapid increase in technological developments, the widespread use of computers and the fact that computers have become mobile and accessible from anywhere, new generation children spend a lot of time in digital games, leading to the criticism that digital games reduce sociability. In line with all these results, the importance of technological tools used in every field has increased [16].

Developing students with high levels of competence and abilities in today's education system is a very challenging task for any instructor. Graduates are expected to possess a wide range of competencies, such as critical thinking, problem-solving and cognitive skills, to enter the job market. The world economic trend is changing rapidly, creating more requirements for students to develop their skills to be experts, flexible and adaptable [8].

Simultaneous streaming of Steven Johnson, Everything Bad Is Good for You, and the media outlook reports the X-rated content in the popular game Grand Theft Auto and the social implications of computer and video games. Video games connoisseurs say that video games are complex, cognitively challenging and emotionally engaging - arguably the most engaging of contemporary popular art formats. Interactive digital media or video games are a powerful new medium. They offer immersive experiences where players solve problems. Players learn more than facts - ways of seeing and understanding problems so that they 'become' different kinds of people. The 'serious games' of business strategy, advertising and entertainment embody these features and point to a future paradigm for e-Learning $[17,26]$. Gaming academics point out how games are transforming the government, industry and perhaps now education. Meanwhile, critics use little social value of games and can even be harmful. In fact, gamers, who are sympathetic to new technologies, do not understand how games work as simulations [20]. To date, very little is known about the consequences of playing games on the cognition rate of those who play them, and there is little work on 'expert' game practice $[19,7,18]$. 
The importance of human capital for business is still the same. Artificial Intelligence can improve the success of the society - something more complex than a robot can. Human resource is a kind of valuable resource, where educating and training potential talents can be continuously improved. In the age of globalisation, companies have trained their employees for better job performance by provided training, such as on-the-job training and project method training such as coaching [1]. The SIMS course uses Business Strategy Game (BSG) simulation to enable students to experience a top management from a team's perspective by experiencing the conditions of competition in the sneaker industry and managing the company $[3,24]$.

If we create the definition for BSG in general, it will be as follows: a computerised business simulation that is widely used in the international sports shoe industry. It is also used in many areas. The game, now in its sixth edition, allows students operating in small groups to compete with different companies in the same industry and control an independent company. The game requires students to make a large number of decisions regarding product pricing, marketing, manufacturing and all aspects of company operations during various decision periods. At the end of each decision period, the decisions taken by the students are analysed in a computer environment and scored according to the predetermined criteria. The BSG allows students to compete in teams (all form a company, team/company will be synonymous here) in a global arena covering four regions - Europe-Africa, North America, Asia-Pacific and Latin America [3,21]. They compete against teams of their class and compare/compare data with worldwide teams/companies. Each company competes head-to-head against shoe companies managed by other teams. Of course, competition plays an important role in this process in terms of experience. Each company sells its own brand to retailers worldwide and to people purchasing online from the company's website.

Computer-based simulation that provides players with an experience in strategy development, team building, decision, empowerment and basic marketing skills is called BSG. For students, they manage their companies in a competitive marketplace against other teams. The BSG, which pushes students into a competitive market environment, also forces them to take risks and anticipate competitor strategies in addition to developing and implementing their own team strategies $[2,3,8]$. In Rusko's [15] study, she stated that technology-supported training facilitated job performance and learning. In other studies, different academics determined the impact of capturing, creating and distributing value in collaboration; managing collaboration in knowledge-based industries and investigating the differences in cooperation in firm sizes. From all these studies, the transfer of technology to the business environment and its importance in the business environment is increasing [14,25]. The purpose of the collaboration depends on why companies choose such a strategy or relationship [13]. Collaboration can improve individual firm performance and significantly improve market positions when carefully managed by firms $[5,12]$

We live in an age in which technology is used in every sector and technological developments are progressing rapidly. At this time, it is important to determine which studies were carried out in the field of BSG and learning strategic management and in which countries these studies were conducted. 


\subsection{Purpose and importance of research}

The general purpose of this research is to analyse the articles obtained through scanning the Web of Science database systematically, by examining them according to the determined themes (BSG and learning strategic management) and by discussing them with other basic concepts. All articles published in the Web of Science database were included in this study.

\section{Limitations}

- This research is limited to documents selected and reviewed in the Web of Science database.

- Content analysis of documents is limited to the six themes mentioned earlier.

\section{$2 \quad$ Method}

In this study, qualitative research methodology was carried out using document analysis and relevant content analysis. The main process in content analysis is to compile data similar to the research within the framework of the determined concepts and themes and to interpret institutions in a way that the reader can understand. Content analysis is a scientific framework that provides systematic analysis of oral, written and other research resources [27].

\subsection{Data collection and analysis}

Within the scope of the BSG and learning strategic management research, a research was carried out by using the keywords 'Business Strategy Game' and 'Learning Strategic Management' in the Web of Science database between 1995 and 2020, and 39 types were determined as a result of this research, as shown in Figure 1. The documents accessed from the Web of Science database were analysed, correlated and adapted, and the data were analysed with content analysis.

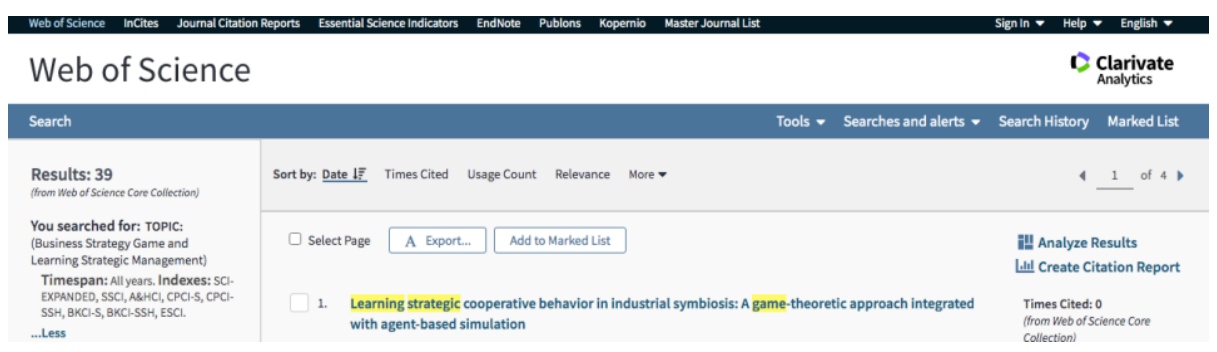

Fig. 1. The documents accessed on the Web of Science database using the keywords 'Business Strategy Game' and 'Learning Strategic Management' 


\section{$3 \quad$ Findings}

\subsection{Findings of the documents by years}

In the research, 39 studies were accessed by browsing the Web of Science database to find studies on 'BSG' and 'learning strategic management'. The distribution of data, of 39 studies, by years is given in Table 1 .

When the findings of the studies on BSG and learning strategic management were examined, it was found that the studies were carried out mostly in 2019. However, the first study was conducted in 1995. It turned out that there were no studies in 2017, 2006, 2004, 2002, 1996, 1997 and 1998.

Table 1. Distribution of the documents by years

\begin{tabular}{|c|c|}
\hline Years & Frequency \\
\hline 2020 & 1 \\
\hline 2019 & 6 \\
\hline 2018 & 3 \\
\hline 2016 & 4 \\
\hline 2015 & 2 \\
\hline 2014 & 4 \\
\hline 2013 & 2 \\
\hline 2012 & 2 \\
\hline 2011 & 3 \\
\hline 2010 & 2 \\
\hline 2009 & 1 \\
\hline 2008 & 1 \\
\hline 2007 & 1 \\
\hline 2005 & 1 \\
\hline 2003 & 1 \\
\hline 2001 & 2 \\
\hline 2000 & 1 \\
\hline 1999 & 1 \\
\hline 1995 & 1 \\
\hline &
\end{tabular}

\subsection{Findings of the documents by document type}

When we examined the studies conducted in the fields of BSG and learning strategic management and scan the Web of Science database, we saw that there were published articles (24) and proceeding papers (15). Articles of different document types were not published in these fields.

Table 2. Distribution of the documents by document type

\begin{tabular}{|l|c|}
\hline \multicolumn{1}{|c|}{ Document type } & f \\
\hline Article & 24 \\
\hline Proceedings paper & 15 \\
\hline
\end{tabular}




\subsection{Findings of the documents by Web of Science categories}

When we look at the distribution of studies in the fields of BSG and learning strategic management, which are among the studies in the Web of Science index, according to the Web of Science categories, we observed that the field of study was education and educational research (16). Again, according to the fields of study, we concluded that there was more work conducted in the field of Management (13). Among these areas, work was also carried out in the Operations Research Management Science (8) area.

Table 3. Distribution of the documents by Web of Science categories

\begin{tabular}{|l|l|}
\hline \multicolumn{1}{|c|}{ Web of Science categories } & f \\
\hline Education and educational research & 16 \\
\hline Management & 13 \\
\hline Operations research management science & 8 \\
\hline Business & 5 \\
\hline Computer science information systems & 3 \\
\hline Computer science artificial intelligence & 2 \\
\hline Computer science interdisciplinary applications & 2 \\
\hline Engineering electrical electronic & 2 \\
\hline Engineering industrial & 2 \\
\hline Psychology social & 2 \\
\hline Social sciences interdisciplinary & 2 \\
\hline Social sciences mathematical methods & 2 \\
\hline Business finance & 1 \\
\hline Computer science cybernetics & 1 \\
\hline Computer science software engineering & 1 \\
\hline Economics & 1 \\
\hline Engineering biomedical & 1 \\
\hline Engineering manufacturing & 1 \\
\hline Engineering multidisciplinary & 1 \\
\hline Environmental studies & 1 \\
\hline Information science library science & 1 \\
\hline Transplantation & \\
\hline
\end{tabular}

\subsection{Findings of the Documents by Research Area}

When the research areas of the studies published in the Web of Science database were examined, it was found that equal research was carried out in the fields of business economics (16) and education and educational research (16). Also, there are eight studies in the field of operations research management science. It was found that the least research areas were in the fields of environmental sciences ecology (1), information science library science (1) and transplantation (1). 
Table 4. Documents by research area

\begin{tabular}{|l|c|}
\hline \multicolumn{1}{|c|}{ Research area } & f \\
\hline Business economics & 16 \\
\hline Education and educational research & 16 \\
\hline Operations research management science & 8 \\
\hline Computer science & 6 \\
\hline Engineering & 6 \\
\hline Mathematical methods in social sciences & 2 \\
\hline Psychology & 2 \\
\hline Social sciences and other topics & 2 \\
\hline Environmental sciences ecology & 1 \\
\hline Information science library science & 1 \\
\hline Transplantation & 1 \\
\hline
\end{tabular}

\subsection{Findings of the Documents by Countries}

Considering the distribution of studies on the themes searched in the Web of Science database by country, it was found that the country with the most studies was USA (12). Germany (4) ranks the second. In the ranking of countries, Canada (3) and Italy (3) rank third. The number of countries where no study has been conducted is quite high.

Table 5. Documents by countries

\begin{tabular}{|l|l|}
\hline \multicolumn{1}{|c|}{ Countries/regions } & f \\
\hline USA & 12 \\
\hline Germany & 4 \\
\hline Canada & 3 \\
\hline Italy & 3 \\
\hline Belgium & 2 \\
\hline England & 2 \\
\hline Ireland & 2 \\
\hline Netherlands & 2 \\
\hline Portugal & 2 \\
\hline Australia & 1 \\
\hline Brazil & 1 \\
\hline Czech Republic & 1 \\
\hline Finland & 1 \\
\hline France & 1 \\
\hline Indonesia & 1 \\
\hline Malaysia & 1 \\
\hline Norway & 1 \\
\hline Russia & 1 \\
\hline Scotland & 1 \\
\hline South Korea & 1 \\
\hline Thailand & 1 \\
\hline
\end{tabular}




\subsection{Findings of the Documents by Languages}

When the written languages of the studies scanned in the Web of Science database were checked, it was found that almost all of the studies were written in English (38) and one study was written in Portuguese.

Table 6. Documents by languages

\begin{tabular}{|l|c|}
\hline \multicolumn{1}{|c|}{ Languages } & f \\
\hline English & 38 \\
\hline Portuguese & 1 \\
\hline
\end{tabular}

\section{Conclusion and Discussion}

In line with the scope of this research, when the distribution of studies on BSG and learning strategic management in the Web of Science database by years was examined, it was concluded that the most studies were carried out in 2019. The result also showed that the first study was conducted in 1995. Considering the technological developments, it is a joy that working in the fields of BSG and learning strategic management has increased in recent years. However, when looking at the distributions by years, there is no slope that goes right. The fact that studies have not been carried out in some years ensures that we cannot follow the current developments in this field.

When we examine the studies in the fields of BSG and learning strategic management and scan the Web of Science database, we concluded that the articles (24) were published as proceeding papers (15). Studies on different types of documents in these areas have not been published. Studies on book chapters and book writings on the BSG and learning strategic management can be carried out.

When we look at the distribution of studies in the fields of BSG and learning strategic management in the Web of Science database by categories, it can be concluded that the most studies were in the field of education and educational research (16). It can be concluded that there are many studies in the field of management (13) in the Web of Science categories database. This situation is the result of the distribution according to the fields within the Web of Science database itself. In this case, we can say that studies in different fields are lacking.

Again, when we examined the research areas of the studies published in the Web of Science database, which is our other finding, it was seen that equal research was carried out in the fields of business economics (16) and education and training research (16). While it was concluded that the most studies in the Web of Science database's own field research were education and educational research, when the research areas of the studies were examined, the field of business economics was included. There are 8 studies in the field of operations research management science [23]. It was concluded that the least research areas were environmental science ecology (1), information science library science (1) and transplantation (1). Substantial research focuses on the importance of teamwork in business management 
$[4,6,9,10,11,22]$. For this reason, it can be said that the studies conducted are high in this field.

Considering the distribution of studies on the themes researched in the Web of Science database by country, the most researched country was USA (12). On looking at the countries of the authors who conducted the studies, Germany (4) ranks the second. In the ranking of countries, Canada (3) and Italy (3) rank the third. The number of countries without studies is quite high. This situation may be related to the state of developed countries in terms of globalisation. USA is a developed country among the countries of the world.

When the written languages of the studies scanned in the Web of Science database were examined, it was concluded that almost all of the studies were in English (38). It was seen that only one study was written in Portuguese. This situation is thought to be related to the fact that English is accepted as a universal language. However, when looking at the distribution by country, it can be said that studies in different languages should be increased.

As a result of this research, suggestions to future researchers are as follows:

There is very little work in the fields of BSG and learning strategic management, therefore more studies should be carried out. This study was conducted in the Web of Science database. Theses related to the field of BSG and learning strategic management should be examined and further studies should be conducted. The number of countries that have not worked on the BSG and Learning Strategic Management area is quite high. Therefore, studies in these countries should be conducted and compared.

\section{Acknowledgements}

1. The work was performed according to the Russian Government Program of Competitive Growth of Kazan Federal University.

2. The work was performed according to the project of improving competitiveness of the leading Russian universities among the leading world scientific education centres "5-100"of First Moscow State Medical University.

3. The work was performed according to the Program of Development of Financial University under the Government of the Russian Federation for 2020.

\section{References}

[1] Brinia, V. (2011). Project: A trainee-oriented training method, an empirical approach. Higher Education, Skills and Work-Based Learning, 1, 169-186. https://doi.org/10.1108/2 0423891111128926

[2] Diaz-Gomez, Y., Angel, Y., \& Hicks, J. (2020). Burst footwear business strategy game. Dominican University of California.

[3] Doyle, D., \& Brown, F.W. (2000). Using a business simulation to teach applied skills - the benefits and the challenges of using student teams from multiple countries. Journal of 
European Industrial Training, 24(6): 330-336. https://doi.org/10.1108/0309059001037331 $\underline{6}$

[4] Enos, L., Kalabokes, M., \& Zamora, J. (2019). Business Strategy Game (BSG). Dominican University of California.

[5] Fernandez, A., LeRoy, F., \& Gnyawali, D. (2014). Sources and management of tension in coopetition case evidence from telecommunications satellites manufacturing in Europe. Industrial Marketing Management, 43(2): 222-235. https://doi.org/10.1016/j.indmarman. $\underline{2013.11 .004}$

[6] Hackman, J. R., \& Wageman, R. (1995). Total quality management: Empirical, conceptual, and practical issues. Administrative Science Quarterly, 40(2): 309-342. https:// doi.org/10.2307/2393640

[7] Jenner, S., Zhao, M., \& Foote, T. H. (2010). Teamwork and team performance in online simulations: The business strategy game. Journal of Online Learning and Teaching, 6(2): 416-430.

[8] Kaliappen, N. (2019). Educational benefits of using Business Strategy Game (BSG) in teaching and learning strategic management. International Journal of Emerging Technologies in Learning (iJET), 14(07): 209-215. https://doi.org/10.3991/ijet.v14i07.979 $\underline{2}$

[9] Katzenbach, J. R., \& Smith, D. K. (2003). The wisdom of teams: Creating the highperformance organization. Harper Collins.

[10] Kourtesopoulou, A., \& Kriemadis, A. (2020). Exploring the influence of Outdoor Management Development (OMD) program on leadership and teamwork competencies. Journal of Adventure Education and Outdoor Learning, 1-14. https://doi.org/10.1080/147 29679.2020.1784763

[11] Lohmann, G., Pratt, M. A., Benckendorff, P., Strickland, P., Reynolds, P., \& Whitelaw, P. A. (2019). Online business simulations: Authentic teamwork, learning outcomes, and satisfaction. Higher Education, 77(3): 455-472. https://doi.org/10.1007/s10734-018-0282$\underline{\mathrm{x}}$

[12] Park, B. (2011). The effects of coopetition and coopetition capability on firm innovation performance [Unpublished thesis, Virginia Polytechnic Institute and State University].

[13] Peng, M. W., Wang, D. Y., \& Jiang, Y. (2008). An institution-based view of international business strategy: A focus on emerging economies. Journal of International Business Studies, 39(5): 920-936. https://doi.org/10.1057/palgrave.jibs.8400377

[14] Pineida, F. (2020). Impact of aggressive online digital marketing on sales in the Latin American and Caribbean regions. Global Journal of Business, Economics and Management: Current Issues, 10(2), 91-99. https://doi.org/10.18844/gjbem.v10i2.4689

[15] Rusko, R. (2013). Exploring the concept of coopetition: A typology for the strategic moves of the Finnish forest industry. Industrial Marketing Management, 40(2): 311-320. https:// doi.org/10.1016/j.indmarman.2010.10.002

[16] Sabirli, Z., \& Coklar, A. (2020). The effect of educational digital games on education, motivation and attitudes of elementary school students against course access. World Journal on Educational Technology: Current Issues, 12(3): 165-178. https://doi.org/10.188 44/wjet.v12i3.4993

[17] Singh, G. B., \& Singh, K. (2020). Predicting intra-game outcomes with neural networks: A paradigm for business strategy. International Journal of Research in Business Studies, 5(1): 2455-2992.

[18] Squire, K. (2005). Game-based learning: Present and future state of the field. Masie Center e-Learning Consortium. 
[19] Squire, K. D. (2008). Video game-based learning: An emerging paradigm for instruction. Performance Improvement Quarterly, 21(2): 7-36. https://doi.org/10.1002/piq.21139 https ://doi.org/10.1002/piq.20020

[20] Squire, K., Giovanetto, L., Devane, B., \& Durga, S. (2005). From users to designers: Building a self-organizing game-based learning environment. TechTrends, 49(5), 34-42. https://doi.org/10.1007/BF02763688

[21] Thompson, A. A., \& Stappenbeck, G. J. (1995). The business strategy game. Irwin.

[22] Wageman, R. (1995). Interdependence and group effectiveness. Administrative Science Quarterly, 40(1): 145-180. https://doi.org/10.2307/2393703

[23] Wageman, R., \& Baker, G. (1999). Incentives and cooperation: The joint effects of task and reward interdependence on group performance. Journal of Organizational Behavior, 18(2): 139-158. Published Online April 28 John Wiley \& Sons, Ltd. https://doi.org/10.10 02/(sici)1099-1379(199703)18:2<139::aid-job791>3.0.co;2-r

[24] Wolfe, J., \& Chanin, M. (1993). The integration of functional and strategic management skills in a business game learning environment. Simulation and Gaming, 24(1), 34-46. https://doi.org/10.1177/1046878193241005

[25] Worimegbe, P. (2020). Coopetition and customers' experience in the Nigerian banking sector: The moderating effect of technology. Global Journal of Business, Economics and Management: Current Issues, 10(2): 111-123. https://doi.org/10.18844/gjbem.v10i2.4847

[26] Pascu, L., Simo, A., \& Vernica, A. M. (2019). Integrating Microsoft IoT, machine learning in a large-scale power meter reading. International Journal of New Trends in Social Sciences, 3(1): 10-16. https://doi.org/10.18844/ijntss.v3i1.3815

[27] Kuloglu, C. (2019). Comparative analysis of the tendency of vocational health school students to have children. International Journal of Emerging Trends in Health Sciences, 3(2): 42-49. https://doi.org/10.18844/ijeths.v3i2.4473

\section{Authors}

Alper Cavus, Near East University, Doctoral Student of Department of Computer Information Systems, Technical Staff of Distance Education Center, Nicosia, Mersin 10, Turkey. Email: alper.cavus@neu.edu.tr

Alfiya R. Masalimova is a Doctor of Education, Professor, Head of the Department of Pedagogy of Higher Education of the Institute of Psychology and Education at Kazan (Volga region) Federal University (18 Kremlyovskaya Street, 420000, Kazan, Russia). She is also the Head of Publication Activity Department of Strategic Academic Unit of Kazan (Volga region) Federal University. Her research interests are connected with the methodology of scientific articles and thesis, mentoring and tutoring, teacher education and training. She has more than 150 published papers in Russian and International journals. E-mail: alfkazan@mail.ru

Vasil N. Farrakhov is PhD in History, Associate Professor of the Department of Economics and Enterprise Management at Almetyevsk State Oil Institute (2 Lenin Street, 423450, Almetyevsk, Russia). His main scientific and professional interests are related to the history, history of the economy, problems and prospects of development of the Russian economy's oil and gas sector. Author of more than 60 articles in Russian and foreign journals. E-mail: farrahov.vasil@yandex.ru 
Svetlana G. Kashina is $\mathrm{PhD}$ in Education, Associate Professor of the Department of Construction Technology at Kazan State University of Architecture and Engineering (1 Street Green, 1420043, Kazan, Russia). Her research interests for the last decade have been largely concerned with the problems of methodology in engineering education and environmental education. She has more than 50 articles published in different Russian and international journals. E-mail: kashina@kgasu.ru

Zhanna M. Sizova is a Doctor of Medicine, Professor, Head of the Department of Urgent and Outpatient Therapy at I.M. Sechenov First Moscow State Medical University (Sechenov University) (8 Trubetskaya Street, 119991, Moscow, Russia). She has more than 120 published articles in Russian and International journals. Her research interests are connected with health care education. E-mail: sizovaklinfarma@mail.ru

Olga V. Popova is $\mathrm{PhD}$ in Law, Associate Professor of the Department of International and Public Law at Financial University under the Government of the Russian Federation (49 Leningradsky prospect, 125993, Moscow, Russia). She has more than 50 published scientific works in Russian and international journals, indexed by Scopus and Web of Science data bases. Her research interests are connected with educational environment problems, educational technologies and economic effectiveness of educational system. E-mail: Helga-popova@yandex.ru

Article submitted 2020-09-17. Resubmitted 2020-10-09. Final acceptance 2020-10-09. Final version published as submitted by the authors. 